\title{
Ruy Galvão de Andrada Coelho
}

\section{FERNANDO AUGUSTO ALBUQUERQUE MOURÁO}

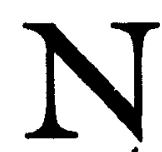

o final da Segunda Guerra Mundial, Ruy Coelho escreveu o artigo Plataforma da Nopa Gerafão, no qual se lê: "O Homem Total é o que será realizado por meio de sangue, suor e lágrimas. É aquele que não está submetido ao Estado, nem vive isolado. Tendo-se apropriado das forças criadoras, poderá desenvolvê-las, fazendo-as convergir para o benefício da comunidade harmoniosa (...)" . Para o jovem Ruy Coelho, a totalidade está adstrita ao próprio homem e acrescenta: " (...) crença no mundo de pós-guerra, como restabelecedor de certos aspectos mutilados da personalidade humana, é parte integrante de mim mesmo". Se uma certa crença na realização da harmonia no pós-guerra resvala para a utopia - trata-se de um dos pontos centrais da crença da sua geração; Ruy Coelho, de 1950 a 1952, trabalhou em Paris, na Unesco, num projeto sobre relaçóes raciais; Eurípedes Simóes de Paula, seu colega, um pouco mais velho, combateu como voluntário ao lado das forças aliadas nesse cenário bélico - a verdade para Ruy Coelho, assim como para Tolstoi, "é a mais bela coisa do mundo", como o afirma Isaiah Berlin, no final de seu ensaio, $A$ Busca do Ideal, texto de abertura de Limites da Utopia, era fundamental. As preocupaçóes do jovem autor de Proust - uma leitura "necessária a quem quer saber o que acontece do outro lado do telefone", na perspectiva de Roger Bastide - Diálogo a uma poz, texto crítico do inesquecível pensador francês acerca do livro de Ruy Coelho, e tema também de um de seus artigos na revista Clima, Marcel Proust e a nossa época - giraram preferencialmente em torno do tema da personalidade humana.

Para Ruy Coelho, formado em Filosofia (1941) e em Ciências Sociais, tendo freqüientado o curso de Direito da USP, "nous ne serons pas sauvés par Freud, pour Marx, par Lépi-Strauss non plus", tal como se lê numa nota à margem de uma conferência que proferiu em Aix-enProvence, La troisieme ripe du fleupe, universidade onde lecionou durante os seus anos de exílio, antes de se transferir para Coimbra, onde ministrou seus últimos cursos. Este manuscrito - que me chegou em mãos graças à gentileza de um familiar seu - traz-me à memória minha estirada de Argel até Aix-en-Provence na busca de um reencontro impossível com o mestre que finalmente revi num edifício pombalino, 
anexo da antiga Faculdade de Ciências da Universidade de Coimbra, onde vivia e lecionava, sempre interessado em saber novidades do Brasil.

Discípulo dileto de Melville Herskovits e de Irving Hallowel, seus mestres na Northrpestern University, e amigo entre outros de Nadel, seguiu cursos em New York, no Instituto Rorschach, na sua infindável busca em torno do seu tema central: a personalidade, de que nos deixou testemunho, através de sua tese de cátedra (1964), Estrutura Social e Dindmica Psicológica. Texto altamente estimulador que, na ocasiáo, me deu a ler em primeira máo quando fui seu assistente na vaga do profes-

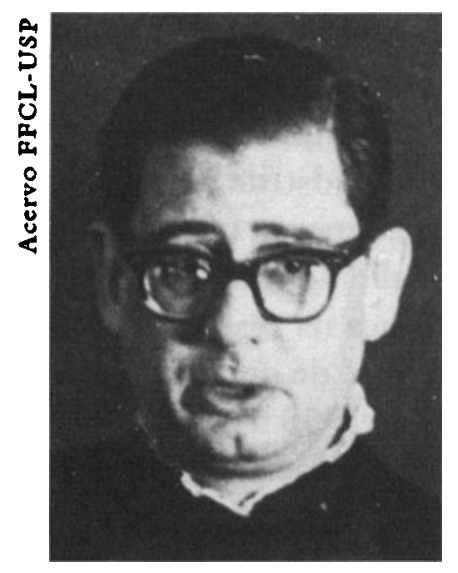

Ruy Coelbo

sor Antônio Cândido, seu amigo. Este, em um texto de homenagem a Ruy Coelho, teve ocasião de pôr em relevo a sua preocupação com o "comportamento do indivíduo no contexto da cultura e da sociedade", ao fazer a ligação entre alguns de seus textos, The significance of the Coupade among the Black Caribs (Man, 1949), e Le concept de l'ame chez les Caraibes Noires (Journal de la Societe des Américanistes, 1952). O mesmo eixo de preocupaçōes está também presente em o Indivtduo e a sociedade na obra de August Comte, sua livre-docência, em que não poupa críticas ao estruturalismo, críticas que retoma em sua tese de cátedra, confrontando os conceitos básicos do estruturalismo com as descobertas no campo da psicologia, terminando seu texto com a frase: "Nas marcas fronteiras das ciências sociais e da psicologia há poucas estradas construídas".

Já nos idos de sua diáspora coimbră, onde deixou igualmente jovens discípulos, Ruy Coelho começou a desenvolver sua percepçáo acerca da importância da contribuição da epistemologia no campo da sociologia, tema sobre o qual discorreu numa conferência realizada no 
Instituto de Estudos Avançados da USP, a convite de Alfredo Bosi, durante uma de suas visitas a São Paulo.

Ruy Coelho, esteta e literato, foi essencialmente um professor, um mestre da oralidade, a que as tarefas administrativas, mormente as de diretor da Faculdade de Filosofia da USP, nunca o afastaram do ensino. Lembro-me dessa convivência harmoniosa que mantinha com os seus jovens discípulos, da ênfase com que colocava o interconhecimento no campo das ciências humanas com que construía suas reflexóes em torno do conhecimento científico hodierno, outrossim, do entusiasmo com que gravava a sua busca da verdade.

Fermando Augusto Albuguerque Mourdo é professor do Departamento de Sociologia da Faculdade de Filosofia, Letras e Ciências Humanas da USP. 